\title{
25. Making votes count: The need for electoral reform
}

\author{
Rev. Akuila Yabaki
}

\section{Introduction}

Fiji will be at the crossroads again in 2009. In a span of 10 years, since the first election under the 1997 constitution was contested in 1999, the country will have had four elections. The 1997 constitution - which ordains the alternative vote (AV) system, the use of a mix of open and communal seats, and the multiparty cabinet concept - had been expected to encourage moderation and accommodation, resulting in a more representative and multi-ethnic cabinet. This, sadly, has not happened. On the contrary, the racial groups have become more polarized, and political parties have played the race card to the maximum. The fact that we have had two coups in the past ten years also clearly shows that things have not worked out in the manner anticipated by the architects of the 1997 constitution.

The Citizens' Constitutional Forum (CCF) conducted an 'Elections Watch' workshop after the 1999, 2001 and 2006 elections. This chapter examines the findings and recommendations made at those workshops.

\section{The expectations and realities of the 1999 election}

The 1999 election did not meet the expectations of the Reeves Commission; it did not deliver political moderation and cooperation. Leaders of the main parties were indeed conscious of the need to work with cross-ethnic partners - for example, the coalition - made up of the Soqosoqo ni Vakavulewa ni Taukei (SVT), the National Federation Party (NFP) and the United General Party (UGP) designated an agreed first-choice candidate in each constituency. But cooperation between the Great Council of Chiefs-supported SVT and the NFP was exclusive rather than inclusive in character. Sitiveni Rabuka, as the leader of the SVT, represented Fijian interests and Jai Ram Reddy, as NFP leader, represented Indo-Fijian interests. Although the leaders claimed to represent entire communities, excluded were those sections with differing ideologies. Cooperation between the parties in the People's Coalition (the Fiji Labour Party, the Fiji Association Party and the Party of National Unity), and to some extent between these parties and the Christian Democrats (VLV, Veitokani ni Lewenivanua Vakarisito), was essentially an anti-SVT/NFP marriage of electoral convenience. Generally speaking, while there was a consensus between the parties on some issues, they remained divided by history. 
'Above the line' voting was introduced to facilitate cross-ethnic electoral agreements. In practice, it meant that candidates did not need to interact with other parties or seek support from wider groups of voters once the agreements to trade preferences were struck by party leaders. Furthermore, the AV system did not guarantee parties fair representation. For example, the NFP won no seats although it polled one-third of the Indian vote.

In 1999, problems with the electoral process included evidence of political pressure placed on some voters (particularly ethnic Fijians).

Despite the existence of 25 open seats, it was suggested that only six seats were genuinely competitive in the sense of having a close balance between ethnic Fijians and Indo-Fijians.

\section{The multiparty system}

Although the Reeves Commission did not recommend mandatory multiparty government in its constitutional review, a decision to introduce this was made by parliament. In the CCF's workshop following the 1999 election, the following points were made in relation to the multiparty cabinet provisions:

- The Constitutional review had not gone far enough in its proposals for multiparty, multi-ethnic government.

- The election results showed that the reality of ethnic-based voting had not changed. The concept of multi-ethnic, multiparty government remained a politician's issue not a people's issue, imposed from above by the constitution.

- There was a conflict between the acceptance by parliament of the Reeves Commission's rejection of proportional representation for parliamentary elections and parliament's decision to base cabinet membership on a certain proportionality of parties' parliamentary representation.

- There were unresolved legal questions as to whether or not parties could set conditions for cabinet membership.

As regards the electoral system, the CCF workshop drew the following conclusions after the 1999 polls:

- The new system was more expensive than the old - at F $\$ 20$ per vote instead of F\$6 per vote.

- Polling station and constituency boundary arrangements needed re-examination. The old system of designating voters to specific polling stations was felt to be more efficient.

- In spite of the good intentions of the framers of the constitution and electoral system, none of the parties had yet fully adjusted themselves to being multiracial in appeal - although the FLP did its best to represent wider social issues. 
- The AV system was characterized as a voting system capable of producing capricious and unrepresentative results. It was noted that the SVT-NFP-UGP coalition won more first preference votes than the FLP but far fewer seats. Consequently, there was doubt that the AV system could form a stable basis on which to build a multiparty cabinet system.

- The election of members to the House of Representatives should be on a proportional basis, to underpin the proportional allocation of cabinet posts.

- There was a need for voter education under any new system.

- The political situation had changed for the better during the period of the constitutional revision. This was attributed to the democratic way in which the constitution was revised, and was reflected by the respect shown to it by all parties at that time.

- There was a need for some revision of the new voting arrangements.

- The party elites failed to engage with the wider electorate (or in some cases their own supporters). This was attributed in part to the introduction of 'above the line' voting.

Generally, there was some feeling of optimism that the spirit of the 1997 constitution, particularly the multiparty concept, was working. However, a year later, on 19 May 2000, a coup was staged by George Speight and his supporters; they claimed that indigenous Fijian land and resources were under threat by an Indo-Fijian-dominated government. The insurgency was brought under control by the military. However, the deposed Indo-Fijian prime minister and his cabinet were not restored to power. Instead, the country went to a fresh election in August-September 2001.

\section{The 2001 election}

The 2001 CCF workshop revealed feelings of unfairness, injustice, hurt and manipulation, particularly among those who lost. For the first time, there were widespread claims that vote-rigging had occurred, although these claims were not given credibility by any of the international election observer missions. The coup had dampened the spirits of many, and may have been the cause of voter apathy, resulting in a lower turnout. The then Supervisor of Elections, Walter Rigamoto, revealed that the voter turnout at the polls was only 78.93 per cent, compared with 90.18 per cent in 1999. This, Rigamoto said, was a significant drop and could be attributed to factors such as apathy, the potentially long voter processing times, discontent with the voting system, and non-prosecution of those who did not vote in 1999. Missing names in the electoral registers also contributed to the low vote.

Rigamoto acknowledged that suggestions had been made that voter intimidation may also have contributed to the low turnout, although there was no real evidence to support this. 
In 1987, 48 per cent of the voter population had not voted; 41 per cent did not vote in 1994. More people voted in 1999 than in the 2001 election. In 1999, invalid votes were around 9 per cent; in 2001, around 12 per cent.

Women's organizations felt that many women were apathetic. Some could not see why they should vote: Since their choices had been overturned in a coup, why should they participate? There were also feelings of fear. Women were scared about what would happen in a new election. The Fiji Women's Rights Movement in 2001 adopted a strategy aimed at helping people to understand democracy, and how free and fair elections are an important part of democracy.

Rigamoto raised the issue that they had been given only a few months to prepare for the election. Concerns were also raised at the CCF workshop that the country had gone to election too soon after the traumatic experience of the 2000 coup. One participant, Ratu Meli Vesikula, asked:

... how on earth can we prepare our people for a general election after a crisis as big as the coup? As far as I can see, there was no meaningful getting together for dialogue or coming closer together of leaders at the very top and at the higher levels of our country from May 2000 last year to the general election this year ... I can still see an impasse. So is a crisis time a good time to turn to the people in an election?

Concern was raised in the 2001 workshop that, while ordinary citizens want to live in a peaceful country, side-by-side, helping one another and caring for one another, the top level of the hierarchy were doing their level best to stop that happening.

People were not ready for the election. They were confused, their sense of justice was insulted. Having just taken part in a general election, they had hoped for something better - perhaps that leaders could get together and revive the parliament that they had elected - but that did not happen.

Other factors that influenced the voting environment included the security forces, the question of the intimidation of voters, the violence that took place in Dawasamu and Muaniweni areas, and threats about possible bloodshed if certain political parties were to win. The mere fact that international observer teams from around the world came to Fiji for the first time was interpreted as a hint of how serious the situation was.

After taking into account the low voter turnout and the number of invalid votes, the government of the country was chosen by only 65.9 per cent of the people. SVT candidate Filipe Bole's calculation that 30 per cent of voters did not vote is close to this figure.

The 2001 election saw political parties exploit to the full the different customs and traditions of the races and cultures in Fiji. Use of the race card characterized 
the 2001 election, as did the promotion of the politics of fear. The winners were the political parties that most successfully exploited and manipulated traditional, ethnic, cultural and religious influences. Overall, these influences compartmentalized the voters, making them less free to express their will.

It was revealed that the Soqosoqo Duavata ni Lewenivanua (SDL) party attempted to avoid the direct verdict of the voters by presenting a tabua to the chiefs of the 14 provinces in order to seek their support and that of their people. This was described as exploitation and manipulation of Fijian tradition. Use of provincial councils to select candidates for political parties, or even to select independents, was another example of manipulation.

The third example of manipulation was the use of religion to promote political parties. It was revealed that Methodist ministers and stewards were directed in writing - by the Methodist church president to campaign for and promote the SDL party. The president of the Methodist church was rewarded for this action by being given a seat in the Senate in 2001 .

Caretaker ministers (in office during the period between the Chandrika Prasad judgment of March 2001 and the election) were accused of not resigning in time, and there were allegations that they misused government resources to promote their party. One of the major concerns associated with such abuse was the so-called 'agriculture scam' which entailed handouts of farming tools, implements etc, amounting to over $\$ 16$ million. These were distributed just prior to the election by caretaker government ministers who had become part of the SDL party.

An interesting observation was made at the 2001 CCF workshop: It was that the issue of justice is perceived differently by Fijians and Indians. For Fijians, the issue of justice was said to be concerned with domination. By contrast, the issue of justice for Indo-Fijians was supposed to be linked to self-respect. This was seen as further fuelling polarization on both sides. Indo-Fijians saw justice as re-assertion of their electoral rights; the SDL and others continued to use the reason 'why we did May 19 was we wanted to take control'.

\section{The 2006 election}

The 2006 results were similar to those of 2001. In fact, the claims of vote-rigging and voter manipulation increased in 2006 , and there were court cases to challenge the results of some seats. The ethnic polarization in the 2006 election can be described as the worst in the history of Fiji, with the SDL winning almost all Fijian seats and the FLP winning almost all the Indo-Fijian seats. None of the other political parties won a single seat. This election played on the worst fears of voters. The moderate political parties were wiped out.

Although the 2006 election results showed a clear failure to achieve the spirit of the 1997 constitution, some hope was rekindled by the subsequent formation 
of a multiparty government of SDL and FLP members in June 2006. However, the SDL's persistence in using racist policies was a clear indication that its commitment to multiculturalism was just a façade. The deteriorating relations between the SDL and the military resulted in the coup of December 2006. This was the first time that the Fiji military had removed a Fijian-dominated government. The reasons given by the military for the 2006 coup date back to the illegal takeovers of parliament in 2000 and 1987. This leads CCF to conclude that Fiji will only be able to move forward after it has reflected deeply on everything that has gone wrong since the 1987 coup, and found a way to mend the damage.

\section{Comparing elections}

Both the 1999 and the 2001 elections were historic in their own ways. The 1999 election was the first under Fiji's new constitution. The 2001 election followed one of the most traumatic periods of Fiji's recent history. Both, then, were conducted at profound transition points: The 1999 one from a long period of racial exclusion to a more open and democratic order; the 2001 election taking the country from a period of governance by an unelected administration to that of an elected one.

In hindsight, perhaps since independence in 1970, we have taken for granted too many things about the electoral system and its ability to contribute to the goals of multiculturalism, national unity and, based on that, sustainable development. The 1977, 1982 and 1987 elections had revolved around competition between the two major communal blocks. Those elections had ultimately been decided by outcomes in the five or six marginal cross-voting seats where the two major blocks approached parity in numbers. It seemed a façade of electoral democracy, but in reality electoral democracy was being driven by communal competition.

Between 1968 and 1971, our leaders negotiated the framework within which elections were to be carried out in an independent Fiji. They preached the virtues of multiculturalism based on appearances of cross-ethnic political exchanges occasioned by the cross-voting seats. Had we taken a step back to reflect after two or three elections, and accepted that the cross-voting seats were largely working like their communal counterparts, we might have redrawn the electoral architecture earlier.

Elections need to be evaluated against a set of standards, as well as in terms of the aspirations they reflect. For a multiracial, multi-ethnic country like Fiji, where the issue of race can be made to assume an overriding significance, the question of electoral legitimacy is even more pressing. Elections must produce legitimate governments. But more than that, they must be seen to produce legitimate governments. 
We have accepted that, for as long as the race card is used divisively in our communities, Fiji will need to have other enabling mechanisms to ensure that government is representative of a large cross-section of all communities. This might not be possible if we rely upon elections alone. Thus, the CCF workshops included discussion of the formation and operation of multiparty government. However, even the introduction of the 1997 constitution's multiparty system has failed to produce accommodation and moderation in Fiji's politics. There is generally a feeling that, although less than before, women continue to be excluded from decision-making and electoral representation processes.

\section{Conclusions and recommendations}

On the basis of its workshops and further research, CCF has drawn the following conclusions.

1. It is important for voters to understand the process of governance, and why and how voting fits into the control over state power. They need to understand why their rights are important. Once people understand their civil and political rights, they can then understand how and why they should demand resources and development for their communities. More education on governance, citizenship, human rights and democratic processes are necessary for these results to occur.

2. If the true spirit of democracy is to be respected, political parties' manifestos and policies should be geared for the development of the whole nation. In Fiji's case, the fact that political parties only cater for particular ethnic groups means that, when they come into power, they do not have a national focus and thus propagate racial divisiveness and prejudice.

3. If racial elements were removed from the electoral system, all parties would be obliged to cater for the needs, aspirations and well-being of all members of the country. A party promoting policies that can be described as racially discriminatory should be disqualified from contesting the election. This would be in line with Fiji's obligations under the Convention on the Elimination of All Forms of Racial Discrimination.

4. The election system has been unkind to those reformed politicians who have publicly acknowledged wrongs. Those who once supported ethnic nationalist policies but came to embrace multiracialism have been treated poorly at the polls by their people. For example, Sitiveni Rabuka, Ratu Meli Vesikula and Ratu Epeli Ganilau have all suffered electoral defeat after such shifts in policy orientation. Fijian society is not providing space for Fijians to hold different views, as should be the case in a democracy. There needs to be more education about the true spirit of democracy, which provides for everyone's rights, needs, and identities to be respected.

5. After the workshop in 2006, CCF recommended that Fiji adopt an electoral system geared towards proportional representation. This could be the only 
way forward for Fiji if the country wants to break out of the post-independence pattern of non-representation for certain ethnic groups in cabinet. The elected leaders of Fiji have shown a general unwillingness to give an appropriate number of seats in cabinet to members of the different ethnic communities. The only way that this problem may be rectified is a proportional representation system - a shift that is particularly important in light of the diminishing population of non-Fijian ethnic groups since the 1987, 2000 and 2006 coups.

6. Fiji needs to find a middle way to resolve the problems that have resulted in the four coups. Clearly, there has been no review of the constitution or the electoral system that might make this possible. In the aftermath of the 2000 and now the 2006 coup, dialogue has not been held to find a middle ground to take the country forward. CCF believes that the current People's Charter process will enable us to find this middle ground. South Africa was able to avoid bloodshed and is moving towards better times after adopting the middle way through the Truth and Reconciliation Commission. Northern Ireland took the middle way by means of dialogue between the two extremes sides, the Protestants and Catholics, who formed two opposing blocks in the population. A Community Relations Commission was formed by civil society representatives that presented a framework outlining what Northern Ireland could look like. Participants explored their differences from a strength-based position and realized that segregation was paralyzing every sector of the country. The Commission created the first integrated school and started inter-community projects. Closer to home, Bougainville, after losses of thousands of lives, has now a peace settlement, involving cooperation between participants. Fiji needs to go the middle way. This middle way can found through the charter process. 